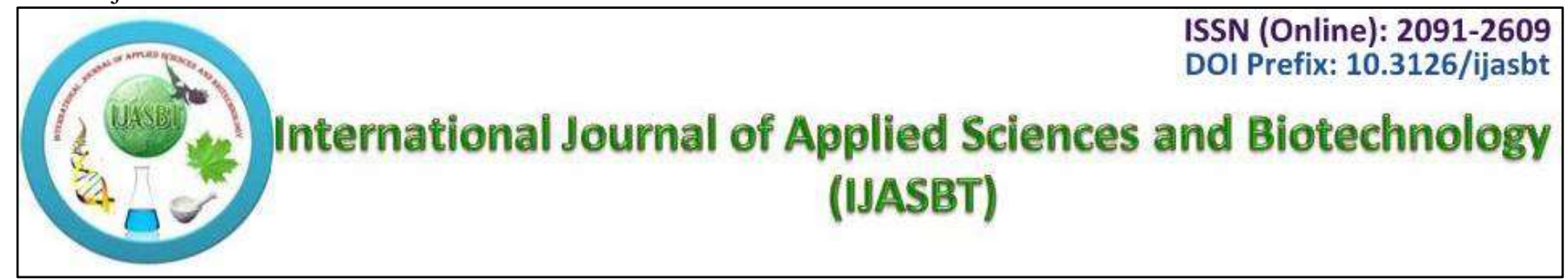

Research Article

\title{
Influence of Annealing on Creep Indentation, Surface Properties and Electrochemical Corrosion Behavior of Ni- Cr Based Dental Alloy
}

\author{
Abu Bakr El-Bediwi ${ }^{1 *}$, Eman Kashita ${ }^{2}$, Salah.M .M. Salman ${ }^{2,3}$ \\ ${ }^{1}$ Physics Department, Faculty of Science, Mansoura University, Egypt \\ ${ }^{2}$ Qassim University, Ministry of High Education, Kingdom of Saudi Arabia \\ ${ }^{3}$ Physics Department, Faculty of Science, Helwan University, Ain-Helwan, Egypt
}

\begin{abstract}
Heat treatment is a process in which alloy is heated to get different microstructures and desired properties associated with it which may affect the corrosion rate, nature form and size. Effect of annealing on microstructure, creep indentation, hardness and electrochemical corrosion behavior of $\mathrm{Ni}_{63} \mathrm{Cr}_{24.6} \mathrm{Mo}_{10.8} \mathrm{Si}_{1.5} \mathrm{Mn}_{0.06} \mathrm{C}_{0.04}$ alloy were investigated. Microstructure of $\mathrm{Ni}_{3} \mathrm{Cr}_{24.6 \mathrm{Mo} 10.8 \mathrm{Si}_{1.5} \mathrm{Mn} 0.06} \mathrm{C}_{0.04}$ alloy changed after annealing at different temperature for two hours. Crystal size of nickel in matrix alloy increased after annealing for two hours at different temperature. Stress exponent, n, Vickers hardness and calculated maximum shear stress of $\mathrm{Ni}_{63} \mathrm{Cr}_{24.6} \mathrm{Mo}_{10.8} \mathrm{Si}_{1.5} \mathrm{Mn}_{0.06} \mathrm{C}_{0.04}$ alloy decreased after annealing. Corrosion rate of $\mathrm{Ni}_{63} \mathrm{Cr}_{24.6} \mathrm{Mo}_{10.8} \mathrm{Si}_{1.5} \mathrm{Mn}_{0.06} \mathrm{C}_{0.04}$ alloy increased after annealing for two hours at different temperature.
\end{abstract}

Key words: microstructure; Vickers hardness; roughness parameters; corrosion, creep

\section{Introduction}

Due to economic reasons, non-precious dental alloys are used more frequently. These are mostly $\mathrm{Co}-\mathrm{Cr}$ and $\mathrm{Ni}-\mathrm{Cr}$ alloys which are considerably cheaper than gold. They have higher tensile strength, their modulus of elasticity is higher and they have less density. Cobalt-chromium alloys today are widely used in prosthetic dentistry for fabrication of removable partial dentures and also for fabrication of some fixed prosthetic appliances (Huang et al., 2005). Nickel alloys are harder than precious metal alloys; they provide the required rigid support for porcelain and prevent fracture. They have been the preferred choice in long-span bridge restorations, or when strength is of main concern (Craig and Peyton, 1975; Smith et al., 1986). Like all nonprecious alloys, nickel alloy are subjected to corrosion products, which might lead to soft tissue inflammation and contact dermatitis (Roitt and Lehner 1980; Ary'kan, 1992). The microhardness of $\mathrm{Ni}-\mathrm{Cr}$ alloys used in fixed prosthodontics after casting under different conditions and the effect of casting technique on surface roughness and consequent mass loss after polishing of $\mathrm{Ni}-\mathrm{Cr}$ and $\mathrm{Co}-\mathrm{Cr}$ base metal alloys was investigated (Bauer et al., 2006; Bezzon et al., 2004). Influence of solute atoms on the surface roughness, microstructure, and mechanical properties (tensile strength and hardness) of $\mathrm{Ni}-\mathrm{Cr}$ alloy was studied and correlated (Das et al., 2010). Also alloying with other elements is required to ensure the achievement of mechanical and corrosion resistance, castability and porcelain bonding (Bezzon et al., 1998; Baran, 1983). The aim of this research was to study the effect of annealing at 700,800 and $900{ }^{\circ} \mathrm{C}$ for two hours on creep process, corrosion parameters and

\section{Article may be cited as}

A.B. El-Bediwi et al. (2017) Int. J. Appl. Sci. Biotechnol. Vol 5(3): 366-374. DOI: http://dx.doi.org/10.3126/ijasbt.v5i3.18295

$1 *$ Corresponding authorAbu Bakr El-Bediwi,

Physics Department, Faculty of Science, Mansoura University, Egypt

Email: baker_elbediwi@yahoo.com

Peer reviewed under authority of IJASBT

(C) 2017 International Journal of Applied Sciences and Biotechnology 
surface properties of $\mathrm{Ni}_{63} \mathrm{Cr}_{24.6} \mathrm{Mo}_{10.8} \mathrm{Si}_{1.5} \mathrm{Mn}_{0.06} \mathrm{C}_{0.04}$ alloy manufactured in Protechno- Vilamalla, Girona, Spain.

\section{Materials and Method}

The specimens used in the present work are $\mathrm{Ni}_{63} \mathrm{Cr}_{24.6} \mathrm{Mo}_{10.8} \mathrm{Si}_{1.5} \mathrm{Mn}_{0.06} \mathrm{C}_{0.04}$ alloy manufactured in Protechno- Vilamalla, Girona, Spain. These samples annealed at 700,800 and $900^{\circ} \mathrm{C}$ for two hours in furnace and stay in until cooled. For all tests as structure, roughness, Vickers microhardness and corrosion behavior, the samples were prepared in convenient shape. Microstructure of used specimens was performed on the flat surface of all specimens using an Shimadzu X-ray Diffractometer (Dx30, Japan), [Metallurgy institute, El-Tebbin, Cairo], of $\mathrm{Cu}-$ $\mathrm{K} \alpha$ radiation with $\lambda=1.54056 \AA$ at $4.5 \mathrm{Kv}$ and $35 \mathrm{~mA}$ and $\mathrm{Ni}$-filter in the angular range $2 \theta$ ranging from 0 to $100^{\circ}$ in continuous mode with a scan speed $5 \mathrm{deg} / \mathrm{min}$. Microhardness test of used specimens were conducted using a digital Vickers microhardness tester, (Model FM-7, Tokyo, Japan), applying a load of 100 gf for 5 seconds via a Vickers diamond pyramid. Ten measurements were recorded for each sample and then the mean value of all measurements was used. The roughness of used samples were measured by using surface roughness measurements device (surface test S.J 201.P). Data are measured numerically and get it from computer program, the program is calculating roughness parameters then plot the result to give roughness profile and different roughness parameters, after that data saved to be analyzed, by calculating the average surface roughness parameter $\mathrm{Ra}$ along the total sliding distance. The polarization studies were performed using Gamry Potentiostat/Galvanostat with a Gamry framework system based on ESA 300. Gamry applications include software DC105 for corrosion measurements, and Echem Analyst version 5.5 software packages for data fitting. Stress exponent was determined using the Mulheam-Tabor method.

\section{Results and Discussion}

\section{$X$-ray Analysis}

Fig. 1 (a-d) shows $\mathrm{x}$-ray diffraction patterns of $\mathrm{Ni}_{63} \mathrm{Cr}_{24.6} \mathrm{Mo}_{10.8} \mathrm{Si}_{1.5} \mathrm{Mn}_{0.06} \mathrm{C}_{0.04}$ alloy before and after annealing at 700,800 and $900{ }^{\circ} \mathrm{C}$ for two hours. The $\mathrm{x}$-ray diffraction patterns showed formed $\mathrm{Cr}_{23} \mathrm{C}_{6}$ (400), $\mathrm{Cr}_{23} \mathrm{C}_{6}$ (331), $\mathrm{Cr}_{23} \mathrm{C}_{6}$ (620) and $\mathrm{Cr}_{23} \mathrm{C}_{6}$ (642) crystalline phases after annealing with changing matrix structure. X-ray analysis for $\mathrm{Ni}_{63} \mathrm{Cr}_{24.6} \mathrm{Mo}_{10.8} \mathrm{Si}_{1.5} \mathrm{Mn}_{0.06} \mathrm{C}_{0.04}$ alloy shows that, intensity (which related to cystallinity) and broadness (which related to crystal size) of diffraction peaks are increased but position of diffraction peaks (which related to orientation) changed after annealing for different temperature at the same time. In addition, intermetallic compound appeared with formed a solid solution during dissolved different atoms in matrix alloy such as Mo, Mn,
$\mathrm{Si}$ and C. Crystal size of nickel in $\mathrm{Ni}_{63} \mathrm{Cr}_{24.6} \mathrm{Mo}_{10.8} \mathrm{Si}_{1.5} \mathrm{Mn}_{0.06} \mathrm{C}_{0.04}$ alloy was calculated using by Scherer formula (Timoshenko and Goodier, 1970) then listed in Table 1. The result shows that, it increased after annealing at 700,800 and $900^{\circ} \mathrm{C}$ for two hours.

Table 1: crystal size of nickel in Ni63Cr24.6Mo10.8Si1.5Mn0.06C0.04 matrix alloy

\begin{tabular}{|l|l|}
\hline Alloys & $\tau(\mathbf{N i}) \mathbf{\AA}$ \\
\hline Based alloy & 19.74 \\
\hline $700{ }^{\circ} \mathrm{C}$ & 50.16 \\
\hline $800{ }^{\circ} \mathrm{C}$ & 63.64 \\
\hline $900{ }^{\circ} \mathrm{C}$ & 86.22 \\
\hline
\end{tabular}

\section{Creep Behavior}

Creep behavior was investigated by indentation method performed at room temperature. The indentation creep data, Fig. 2a, where the indentation length is plotted versus the indentation time at constant loads of 100, 200 and $300 \mathrm{~g}$. These figures show that, the indentation length increases with the loading time and the applied load. Also the curves consist of two stages similar to an ordinary creep curve. The first stage of the curve records an increase in the indentation length with loading time, with a decreasing rate, followed by a steady-state region where indentation sizes increase linearly with time. As the hardness test is actually a compression test, fracture of the specimen dose not occurs and hence it is obviously not possible to record a third stage of the curve as opposed to what happens in an ordinary creep test.

In the Mulheam-Tabor method, Fig. 2b, Vickers hardness number of $\mathrm{Ni}_{63} \mathrm{Cr}_{24.6} \mathrm{Mo}_{10.8} \mathrm{Si}_{1.5} \mathrm{Mn}_{0.06} \mathrm{C}_{0.04}$ alloy before and after annealing for different temperature at two hours is plotted versus indentation time on log-log scale for the indentation data. There exists a linear relationship between indentation time and hardness for all conditions. The slope of the resultant lines according Mulheam-Tabor method is $-\left(n+\frac{1}{2}\right)$ where $\mathrm{n}$ is the stress exponent. The stress exponent values of $\mathrm{Ni}_{63} \mathrm{Cr}_{24.6} \mathrm{Mo}_{10.8} \mathrm{Si}_{1.5} \mathrm{Mn}_{0.06} \mathrm{C}_{0.04}$ alloy before and after annealing for different temperature at two hours are given in Table 2. These exponent values are in the range of 18.02 to 12.49 depending on annealing temperature of used alloy. The change in stress exponent values are attributable to microstructural features, (changing in $\beta$ matrix such as change in the lattice parameters, solid solution, size and distribution of strengthening phases, intermetallic phases). With increasing the grain size, the grain boundary decreased which on dislocation movement affecting on stress exponent values. 
Table 2:- Stress exponent of $\mathrm{Ni}_{63} \mathrm{Cr}_{24.6} \mathrm{Mo}_{10.8} \mathrm{Si}_{1.5} \mathrm{Mn}_{0.06} \mathrm{C}_{0.04}$ alloy

\begin{tabular}{|l|l|}
\hline Alloys & Stress exponent \\
\hline Based alloy & 18.02 \\
\hline $700{ }^{\circ} \mathrm{C}$ & 15.63 \\
\hline $800{ }^{\circ} \mathrm{C}$ & 13.72 \\
\hline $900{ }^{\circ} \mathrm{C}$ & 12.49 \\
\hline
\end{tabular}

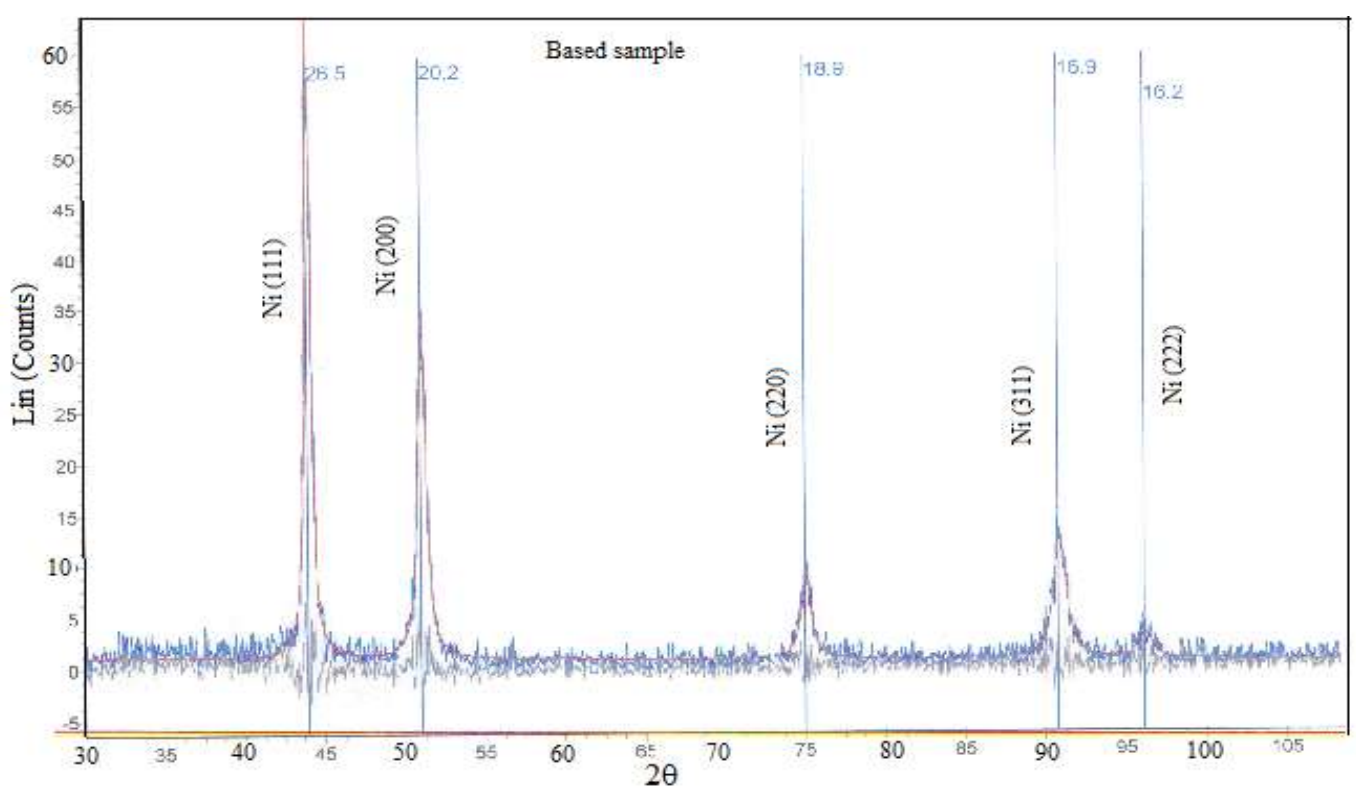

Fig. 1a: x-ray diffraction patterns of based sample

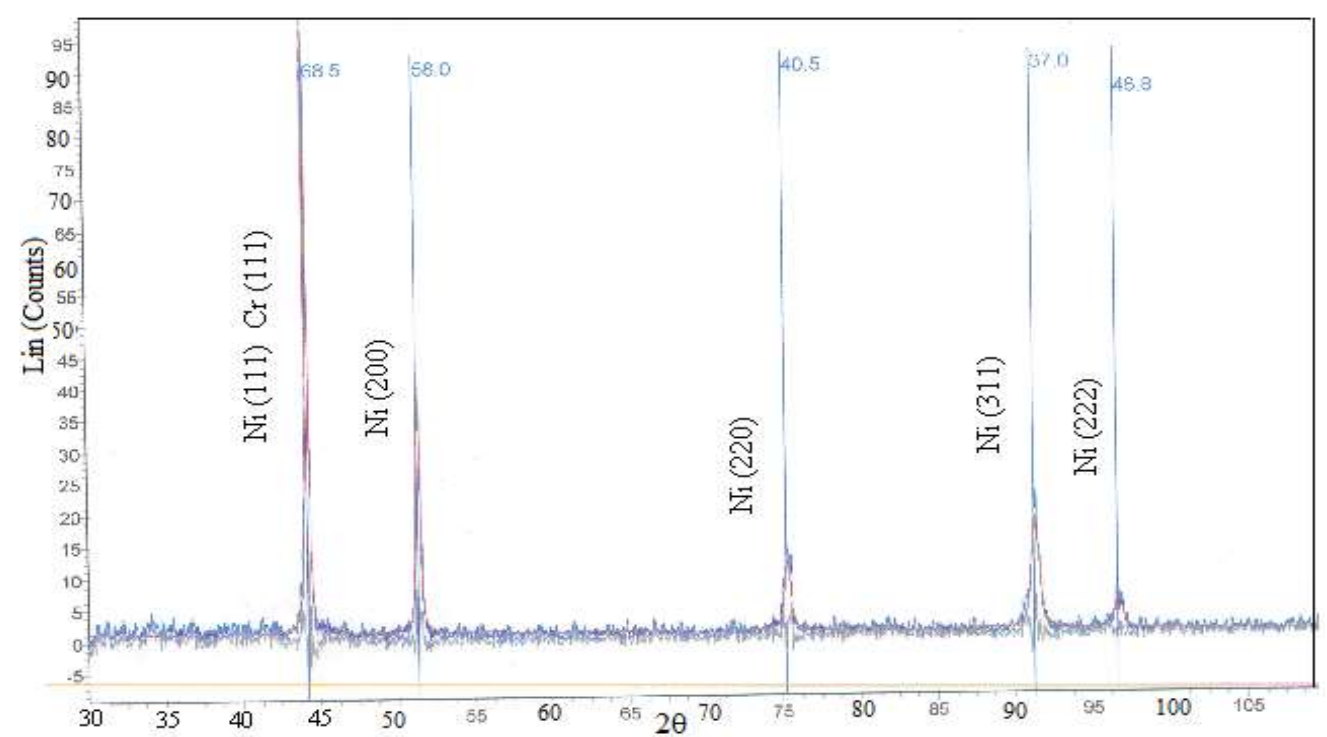

Fig. 1b: x-ray diffraction patterns after annealed at $700{ }^{\circ} \mathrm{C}$ for 2 hours 


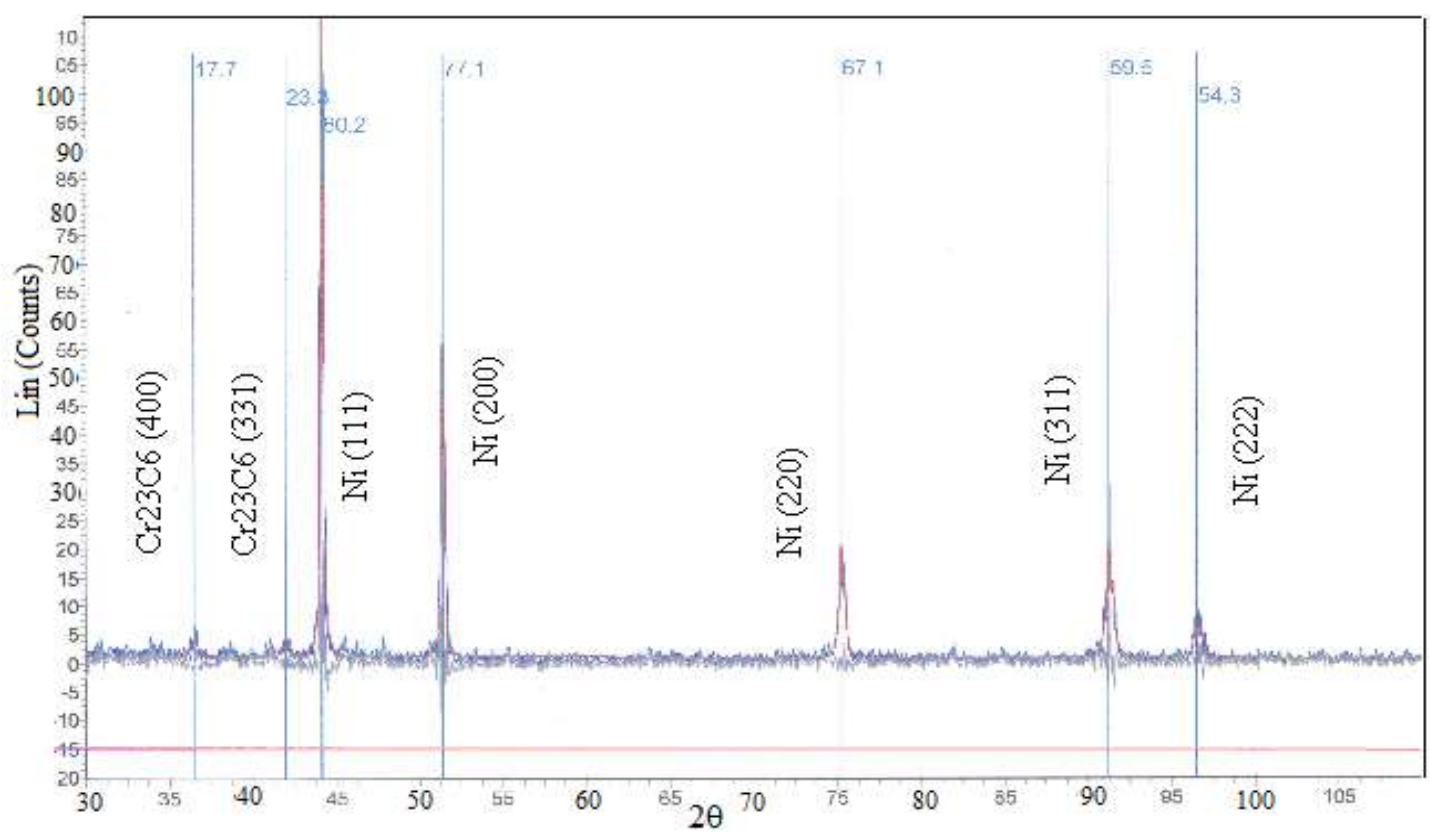

Fig. 1c: $\mathrm{x}$-ray diffraction patterns after annealed at $800{ }^{\circ} \mathrm{C}$ for 2 hours

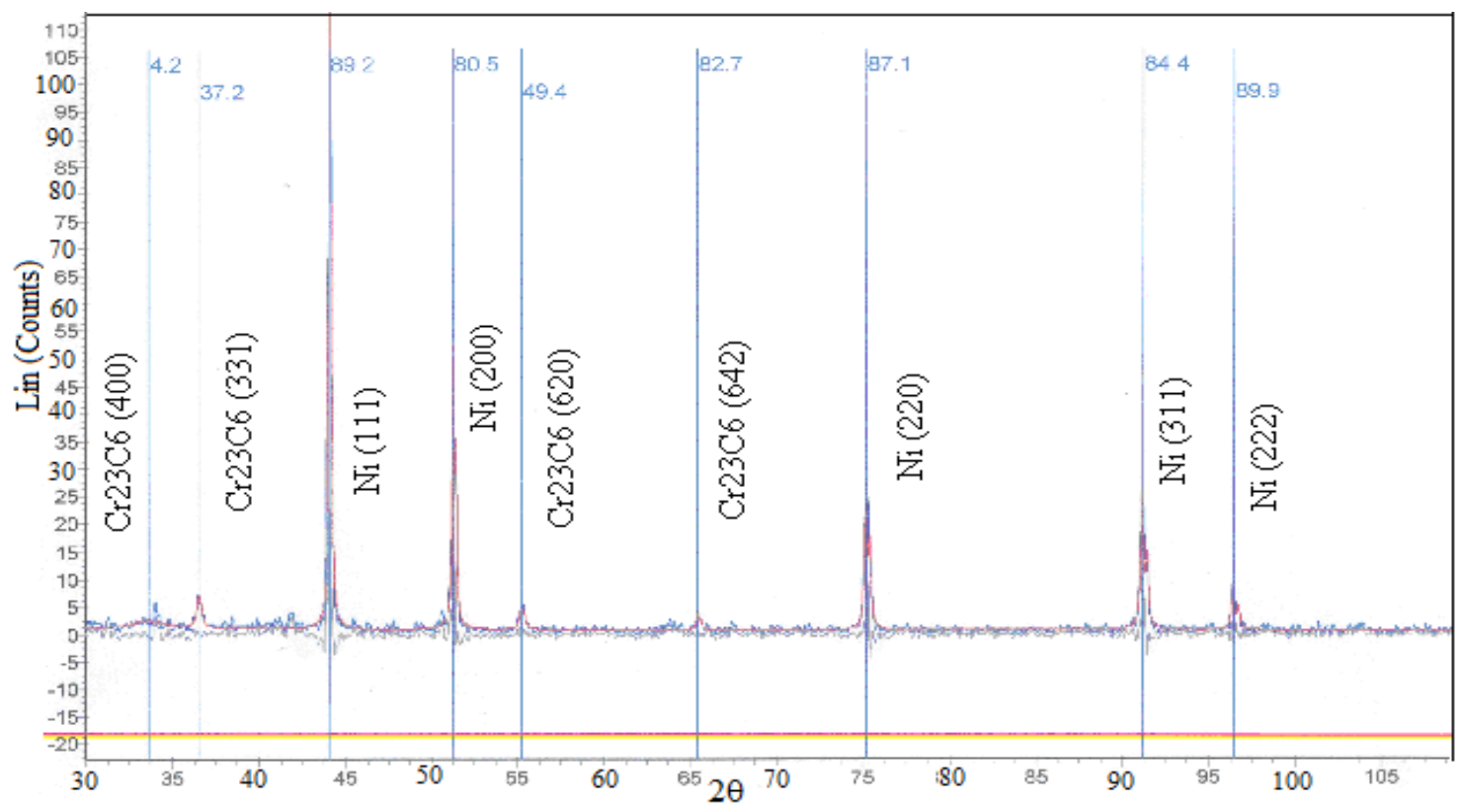

Fig. 1d: $x$-ray diffraction patterns after annealed at $900{ }^{\circ} \mathrm{C}$ for 2 hours 

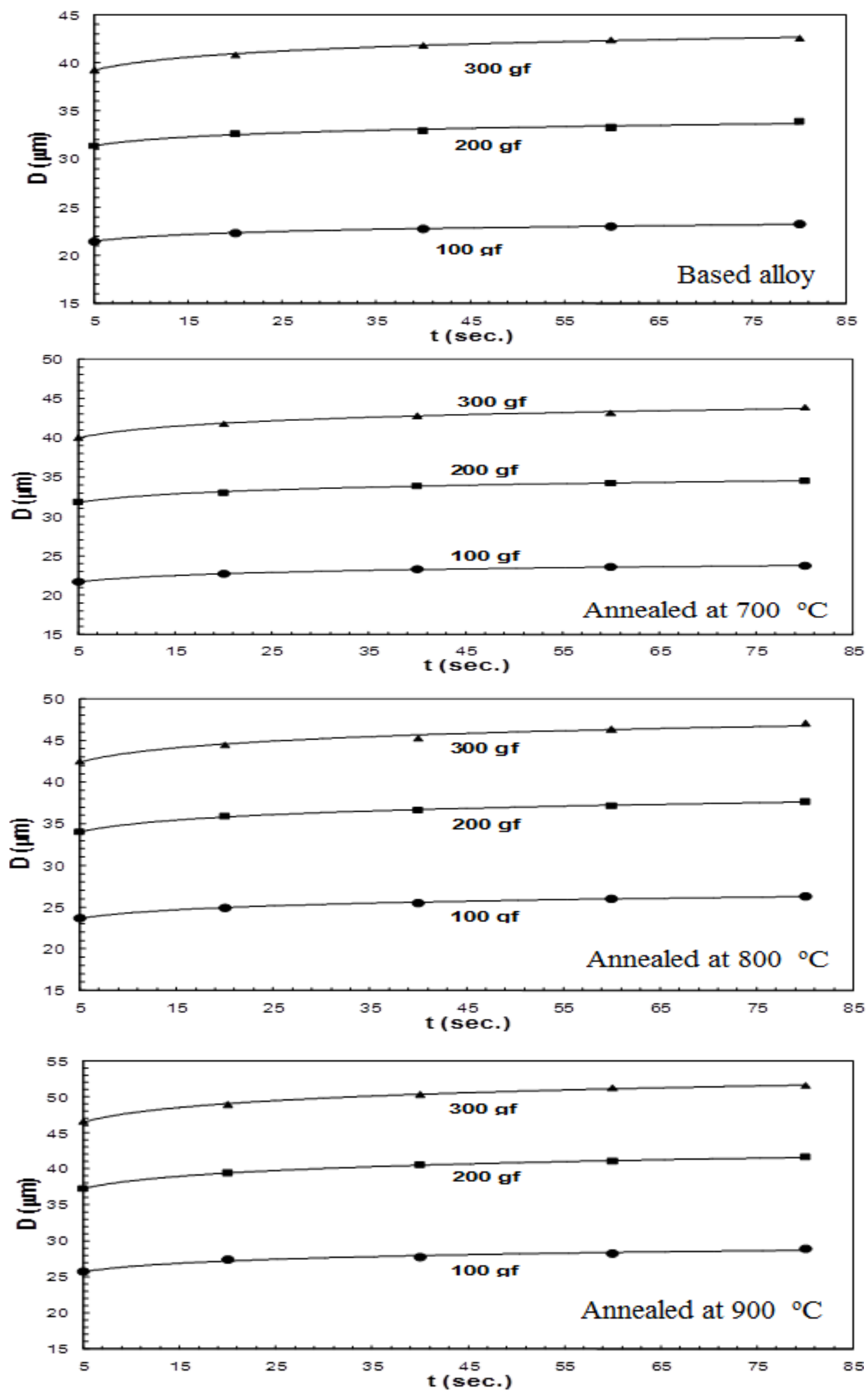

Fig. 2a: Indentation length versus indentation time for $\mathrm{Ni}_{63} \mathrm{Cr}_{24.6} \mathrm{Mo}_{10.8} \mathrm{Si}_{1.5} \mathrm{Mn}_{0.06} \mathrm{C}_{0.04}$ alloy 

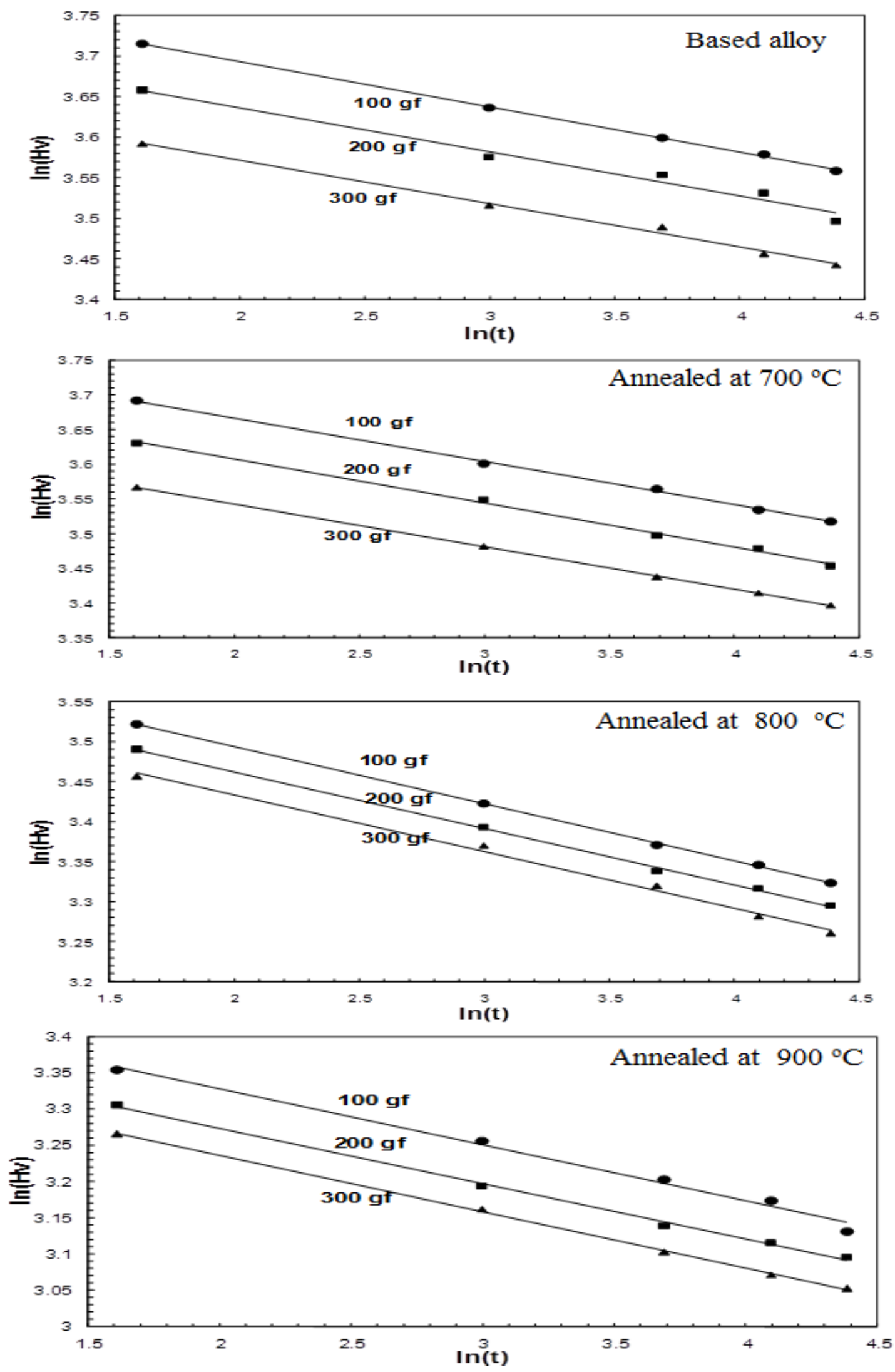

Fig. 2b: $\log$ Vickers hardness versus log indentation time for $\mathrm{Ni}_{63} \mathrm{Cr}_{24.6} \mathrm{Mo}_{10.8} \mathrm{Si}_{1.5} \mathrm{Mn}_{0.06} \mathrm{C}_{0.04}$ alloy

\section{Surface Properties}

\section{Vickers Hardness}

Measured Vickers hardness and calculated maximum shear stress of $\mathrm{Ni}_{63} \mathrm{Cr}_{24.6} \mathrm{Mo}_{10.8} \mathrm{Si}_{1.5} \mathrm{Mn}_{0.06} \mathrm{C}_{0.04}$ alloy decreased after annealing at 700,800 and $900{ }^{\circ} \mathrm{C}$ for two hours as seen in Table 3. That is because the annealing changed crystal size with disturbed a solid solution, (dissolved $\mathrm{Mo}, \mathrm{Mn}, \mathrm{Si}$ and $\mathrm{C}$ atoms) and formed more phases such as $\mathrm{Cr}-\mathrm{C}$ intermetallic compound. 
Table 3: Vickers hardness and calculated maximum shear stress of $\mathrm{Ni}_{63} \mathrm{Cr}_{24.6} \mathrm{Mo}_{10.8} \mathrm{Si}_{1.5} \mathrm{Mn}_{0.06} \mathrm{C}_{0.04}$ alloy

\begin{tabular}{|l|l|l|}
\hline Alloys & $\mathbf{H}_{\mathbf{v}} \mathbf{~ k g} \backslash \mathbf{m m}^{\mathbf{2}}$ & $\boldsymbol{\mu}_{\mathbf{m}} \mathbf{~ k g} \backslash \mathbf{m m}^{\mathbf{2}}$ \\
\hline Based alloy & $402.7 \pm 13$ & 132.66 \\
\hline $700{ }^{\circ} \mathrm{C}$ & $393.4 \pm 17$ & 129.69 \\
\hline $800{ }^{\circ} \mathrm{C}$ & $322 \pm 23$ & 106.26 \\
\hline $900{ }^{\circ} \mathrm{C}$ & $280.7 \pm 22$ & 92.4 \\
\hline
\end{tabular}

\section{Roughness}

The roughness profiles of $\mathrm{Ni}_{63} \mathrm{Cr}_{24.6} \mathrm{Mo}_{10.8} \mathrm{Si}_{1.5} \mathrm{Mn}_{0.06} \mathrm{C}_{0.04}$ alloy before and after annealing at 700,800 and $900{ }^{\circ} \mathrm{C}$ for two hours.is shown in Fig. 3. The average surface roughness parameter $\mathrm{Ra}$ along the total sliding distance increased after annealing as shown in Table 4. Also other roughness parameters changed after annealing.

Table 4:- roughness parameters of $\mathrm{Ni}_{63} \mathrm{Cr}_{24.6} \mathrm{Mo}_{10.8} \mathrm{Si}_{1.5} \mathrm{Mn}_{0.06} \mathrm{C}_{0.04}$ alloy before and after annealing

\begin{tabular}{|l|l|l|l|l|}
\hline \multirow{2}{*}{$\begin{array}{l}\text { Roughness } \\
\text { parameters }\end{array}$} & \multicolumn{5}{|c|}{ Samples } \\
\cline { 2 - 5 } & base & $\mathbf{7 0 0}^{\circ} \mathbf{C}$ & $\mathbf{8 0 0}^{\circ} \mathbf{C}$ & $\mathbf{9 0 0}^{\circ} \mathbf{C}$ \\
\hline $\mathrm{R}_{\mathrm{a}}$ um & 0.40 & 0.43 & 0.45 & 0.56 \\
\hline $\mathrm{R}_{\mathrm{z}}$ um & 1.81 & 2.29 & 1.99 & 3.40 \\
\hline $\mathrm{R}_{\mathrm{q}}$ um & 0.49 & 0.53 & 0.55 & 0.75 \\
\hline $\mathrm{R}_{\mathrm{t}}$ um & 3.35 & 3.03 & 2.58 & 6.02 \\
\hline $\mathrm{R}_{\mathrm{p}}$ um & 0.86 & 1.17 & 0.97 & 1.43 \\
\hline
\end{tabular}
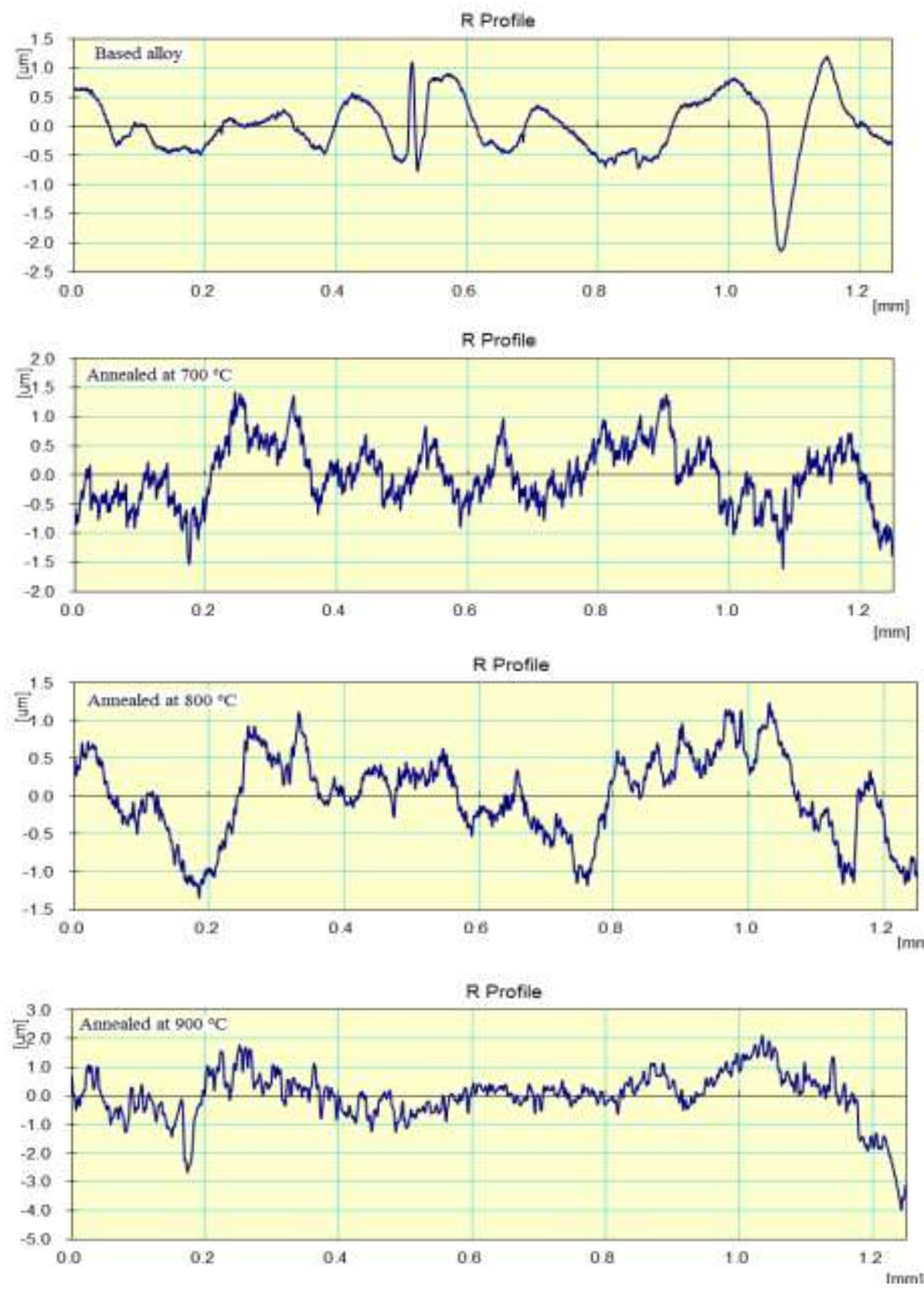

Fig. 3: roughness profiles of $\mathrm{Ni}_{63} \mathrm{Cr}_{24.6} \mathrm{Mo}_{10.8} \mathrm{Si}_{1.5} \mathrm{Mn}_{0.06} \mathrm{C}_{0.04}$ alloy before and after annealing 


\section{Electrochemical Behavior and Parameters}

Electrochemical polarization curves of $\mathrm{Ni}_{63} \mathrm{Cr}_{24.6} \mathrm{Mo}_{10.8} \mathrm{Si}_{1.5} \mathrm{Mn}_{0.06} \mathrm{C}_{0.04}$ alloy before and after annealing at 700,800 and $900{ }^{\circ} \mathrm{C}$ for two hours in $0.25 \mathrm{M}$ $\mathrm{HCl}$ are shown in Fig. 4. The corrosion potential of $\mathrm{Ni}_{63} \mathrm{Cr}_{24.6} \mathrm{Mo}_{10.8} \mathrm{Si}_{1.5} \mathrm{Mn}_{0.06} \mathrm{C}_{0.04}$ alloy before and after annealing at 700,800 and $900{ }^{\circ} \mathrm{C}$ for two hours exhibited a negative potential. Also the cathodic and the anodic polarization curves exhibited similar corrosion trends. The corrosion current $\left(\mathrm{I}_{\text {Corr }}\right)$, corrosion potential $\left(\mathrm{E}_{\mathrm{Corr}}\right)$ and corrosion rate (C. R) of $\mathrm{Ni}_{63} \mathrm{Cr}_{24.6} \mathrm{Mo}_{10.8} \mathrm{Si}_{1.5} \mathrm{Mn}_{0.06} \mathrm{C}_{0.04}$ alloy before and after annealing at 700,800 and $900{ }^{\circ} \mathrm{C}$ for two hours in $0.25 \mathrm{M} \mathrm{HCl}$ are presented in Table 5 . Corrosion rate $\mathrm{Ni}_{63} \mathrm{Cr}_{24.6} \mathrm{Mo}_{10.8} \mathrm{Si}_{1.5} \mathrm{Mn}_{0.06} \mathrm{C}_{0.04}$ alloy before and after annealing increased after annealing.
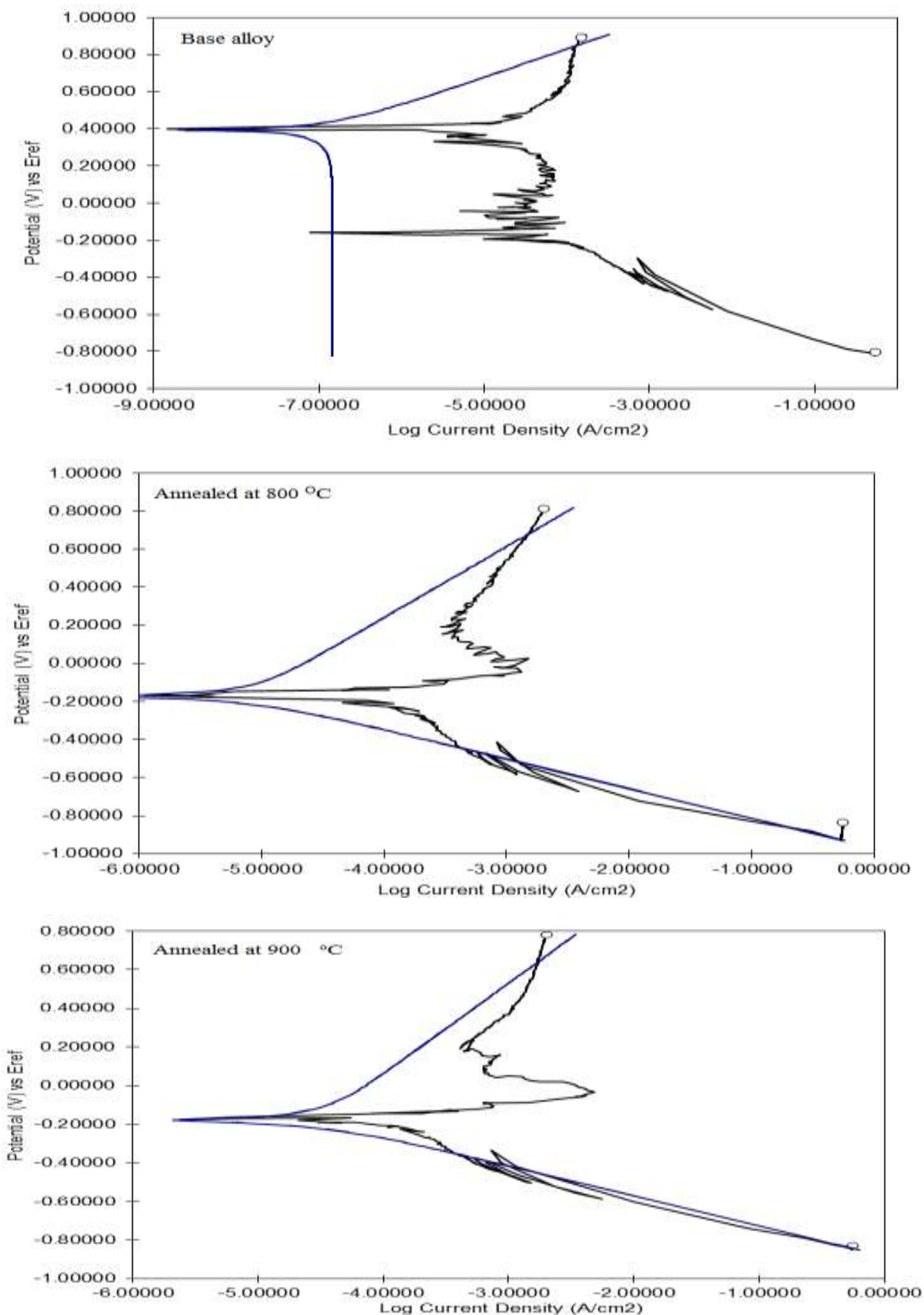

Fig. 5: Electrochemical polarization curves of $\mathrm{Ni}_{63} \mathrm{Cr}_{24.6} \mathrm{Mo}_{10.8} \mathrm{Si}_{1.5} \mathrm{Mn}_{0.06} \mathrm{C}_{0.04}$ alloy before and after annealing 
Table 5: Corrosion parameters of $\mathrm{Ni}_{63} \mathrm{Cr}_{24.6} \mathrm{Mo}_{10.8} \mathrm{Si}_{1.5} \mathrm{Mn}_{0.06} \mathrm{C}_{0.04}$ alloy before and after annealing

\begin{tabular}{|l|l|l|l|l|}
\hline Alloys & $\mathbf{E}_{\text {corr }} \mathbf{m V}$ & $\mathbf{I}_{\text {corr }} \boldsymbol{\mu A} / \mathbf{c m}^{2}$ & $\mathbf{C} . \mathbf{R} \mathbf{~ m m} / \mathbf{y r}$ & $\mathbf{R p} \mathbf{O h m} \mathbf{c m}^{\mathbf{2}}$ \\
\hline Based alloy & 394.7 & 0.1465 & 0.002 & $4.555 \mathrm{E}+05$ \\
\hline $800{ }^{\circ} \mathrm{C}$ & -174.3 & 7.754 & 0.098 & $6.154 \mathrm{E}+03$ \\
\hline $900{ }^{\circ} \mathrm{C}$ & -180.9 & 30.6 & 0.388 & $1.659 \mathrm{E}+03$ \\
\hline
\end{tabular}

\section{Conclusion}

1. Crystal size of nickel phase in $\mathrm{Ni}_{63} \mathrm{Cr}_{24.6} \mathrm{Mo}_{10.8} \mathrm{Si}_{1.5} \mathrm{Mn}_{0.06} \mathrm{C}_{0.04}$ alloy increased with increasing annealing temperature.

2. Vickers hardness and stress exponent of $\mathrm{Ni}_{63} \mathrm{Cr}_{24.6} \mathrm{Mo}_{10.8} \mathrm{Si}_{1.5} \mathrm{Mn}_{0.06} \mathrm{C}_{0.04}$ alloy decreased with increasing annealing temperature.

3. Roughness parameter, $\mathrm{a}$, $\mathrm{Ni}_{63} \mathrm{Cr}_{24.6} \mathrm{Mo}_{10.8} \mathrm{Si}_{1.5} \mathrm{Mn}_{0.06} \mathrm{C}_{0.04}$ alloy increased with increasing annealing temperature.

4. Corrosion rate of $\mathrm{Ni}_{63} \mathrm{Cr}_{24.6} \mathrm{Mo}_{10.8} \mathrm{Si}_{1.5} \mathrm{Mn}_{0.06} \mathrm{C}_{0.04}$ alloy increased with increasing annealing temperature.

\section{References}

Ary'kan A (1992) Effects of nickel-chrome dental alloys used in dentistry on saliva and serum nickel levels, peripheral,Tlymphocytes and some other blood parameters. J. Oral Rehabil.19 (4):343- 352. DOI: $10.1111 / \mathrm{j} .1365-$ 2842.1992.tb01576.x

Baran GR (1983) The metallurgy of Ni-Cr alloys for fixed prosthodontics. The Journal of prosthetic dentistry. 50(5): 639-650. DOI: $\underline{10.1016 / 0022-3913(83) 90201-9}$

Bauer JR, Loguercio AD, Reis A and Rodrigues Filho LE (2006) Microhardness of $\mathrm{Ni}-\mathrm{Cr}$ alloys under different casting conditions. Brazilian oral research. 20(1): 40-46. DOI: $\underline{10.1590 / \mathrm{S} 1806-83242006000100008}$

Bezzon OL, de Mattos MG, Ribeiro RF and Rollo JM (1998) Effect of beryllium on the castability and resistance of ceramometal bonds in nickel-chromium alloys. J Prosthet Dent 80(5): 570- 574. DOI: 10.1016/S00223913(98)70034-4

Bezzon OL, Pedrazzi H, Zaniquelli O and da Silva TB (2004) Effect of casting technique on surface roughness and consequent mass loss after polishing of $\mathrm{NiCr}$ and $\mathrm{CoCr}$ base metal alloys: a comparative study with titanium. The Journal of prosthetic dentistry. 92(3): 274-277. DOI: 10.1016/j.prosdent.2004.04.021

Craig GR and Peyton AF (1975) Restorative Dental Materials, the C. V. Mosby, Saint Louis, 362.

Das S, Seol JB, Kim YC, Park CG (2010) Structure and mechanical properties of $\mathrm{Ni}-\mathrm{Cr}$ alloy produced by single roll strip casting. Materials \& Design 31(1): 570-573. DOI: $\underline{10.1016 / \text { j.matdes.2009.07.006 }}$

Huang HH, Lin MC, Lee TH, Yang HW, Chen FL and Wu SC (2005) Effect of chemical composition of Ni-Cr dental casting alloys on the bonding characterization between porcelain and metal. Journal of oral rehabilitation 32(3): 206-212. DOI: 10.1111/j.1365-2842.2004.01411.x

Roitt IM and Lehner T (1980) Immunology of Oral Diseases, Blackwell Scientific Publications, Oxford, 208

Smith GNB, Wright PS and Brown D (1986) The Clinical Handling of Dental Materials, IOP Publishing Limited Techno House Radcliffe Way, Bristol, 80: 128

Timoshenko S and Goodier JN (1970) Theory of Elasticity (3rd ed) McGraw-Hill, New York. 24: 142. 